\title{
RNAi: A Guide to Gene Silencing, edited by Gregory J. Hannon. 2003. Cold Spring Harbor Laboratory Press, Cold Spring Harbor, NY. ISBN: 0-87969-641-9.
}

The innocent observer standing on a shoreline in the RNA World may feel that a tidal wave has recently surged past. The debris left behind is an alphabet soup of new terminology. Acronyms like RNAi, shRNA, siRNA, stRNA, miRNA, RISC, TGS, PTGS, RdRP, RdDM, SID, and Dicer litter the beach. These refer to only some of the novel cellular components or phenomenology that must be incorporated into current thinking about how cells in the vast majority of eukaryotic organisms manage to survive and differentiate. The RNA World has expanded significantly with the discovery of a new genre of small RNA molecules, the small silencing RNAs (siRNAs) and the microRNAs (miRNAs). In the wake of the wave have sprouted kits and companies-designed to do everything from knock down expression of your favorite gene to cure hepatitis.

RNA enthusiasts can all rejoice in this sudden explosion in the cellular RNA population and marvel at the new respect afforded RNA by the larger community. But, in a field where the literature includes nearly as many minireviews as primary papers, what good is a book? Even Greg Hannon, in his Introduction to the new volume entitled RNAi: A Guide to Gene Silencing, just issued by Cold Spring Harbor Laboratory Press, admits that "it is difficult to predict a future that will still be the future by the time this volume is published." It is its breadth and inclusiveness that make this book a most valuable compendium.

The volume contains 18 chapters, authored by most of the major players in the field. Each chapter provides its own distinctive mix of history, current progress, and future perspectives. Laboratory protocols appear at the end of seven of the chapters.

The individual chapters review everything from the genetics to the biochemistry of RNAi in the most intensely studied organisms - plants, nematodes, flies, and mammals. Not just the standard in vitro and in vivo systems are considered, but also mouse oocytes and preimplantation embryos, and chicken embryos ("What does in ovo RNAi do for me?"). The spectrum of coverage even extends to a valuable chapter on RNAi in trypanosomes and other nonclassical organisms.

Article and publication are at http://www.rnajournal.org/cgi/doi/ 10.1261/rna.5244104.
Many chapters include evolutionary perspectives, for instance, exploring the relationships between transposons and heterochromatin, viroids and DNA methylation, Fragile X syndrome and the RNAi machinery. Valuable inclusions are two chapters providing in-depth reviews of the enzymes in the RNase III superfamily (to which Dicer belongs) and RNA-dependent RNA polymerase (RdRP). Important applications, such as performing genome wide screens using RNAi in both plants and Caenorhabditis elegans, are described, emphasizing the immense practical value of the new technology for functional genomics.

I suspect that the laboratory protocols are the sections of the book that will most rapidly become dated. But their inclusion has occasioned a most curious and somewhat amusing appendix, entitled Cautions, that is cited again and again. It lists as "Hazardous Materials" such substances as glycine, potassium chloride, and-you guessed it—ethanol! The reader is admonished that these "may be harmful by inhalation, ingestion, or skin absorption. Wear gloves and safety glasses." Admittedly, genuinely hazardous chemicals, such as acrylamide, ethidium bromide, and sodium azide, and precautions for handling them are also featured.

I would much rather have seen the seven pages of Cautions devoted instead to a glossary defining terms such as the acronyms above, most of which appear over and over in the book. There is an Index, which is quite extensive and does include multiple page references for each of these terms, but its use requires lots of page turning. A more inclusive table of contents, listing the subheadings in each chapter and whether a protocol is attached, would have increased the value of the book as a reference.

Overall, having everything in one place is what makes RNAi: A Guide to Gene Silencing greater than the sum of its parts. For student and expert alike, it is easier to grab one volume than a sheaf of reprints. What will be most fun will be to reexamine the book in 10 year's time and see to what totally unexpected shores the tidal wave of RNAi has taken us.

Joan A Steitz, Howard Hughes Medical Institute, Yale University School of Medicine, New Haven, CT 06536, USA; e-mail: joan.steitz@yale.edu 

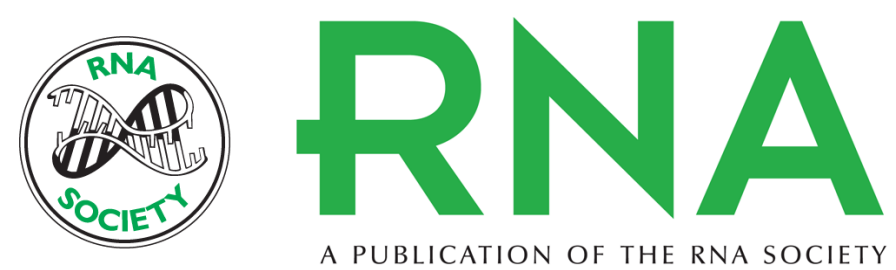

\section{RNAi: A Guide to Gene Silencing, edited by Gregory J. Hannon. 2003. Cold Spring Harbor Laboratory Press, Cold Spring Harbor, NY. ISBN: 0-87969-641-9.}

Joan A Steitz

RNA 2004 10: 350

License

Email Alerting Receive free email alerts when new articles cite this article - sign up in the box at the Service top right corner of the article or click here.

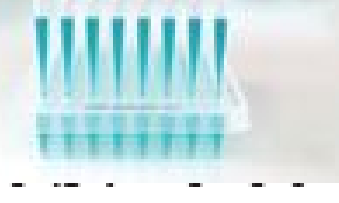

Providing Precise Solutions for your research.

To subscribe to RNA go to:

http://rnajournal.cshlp.org/subscriptions 